Gabriela Abrasowicz

Silesian University in Katowice

abrasowicz.gabriela@gmail.com

ORCID: 0000-0002-2977-4822

\title{
O scenicznym ożywianiu i potencjałach autobiograficznego archiwum na przykładzie wybranych chorwackich spektakli teatralnych*
}

\begin{abstract}
Abrasowicz Gabriela, O scenicznym ożywianiu i potencjałach autobiograficznego archiwum na przykladzie wybranych chorwackich spektakli teatralnych (About Enlivening on Stage and Potentials of the Autobiographical Archive Illustrated by Selected Croatian Theatrical Performances). "Poznańskie Studia Slawistyczne" 19. Poznań 2020. Publishing House of the Poznan Society for the Advancement of the Arts and Sciences, Adam Mickiewicz University, pp. 253-271. ISSN 2084-3011.
\end{abstract}

Autobiographism has been noticeably conquering the Croatian theatre which results in specific artistic projects, mainly falling into the category of theatre of the real. This material calls for a description of strategies, functions and potentials. The most important here is the freedom to (re)construct identity - performativity - communication and interaction. The styling of an autobiographical archive and its extension into action allows adopting a new view and interpreting historical events and current social problems differently. This phenomenon is manifested in selected performances which involve staging a dramatic text, adapting prose or journalistic text, compiling and processing various cultural texts, incorporating the performers' confessions and observations, and developing documentary material. Descriptions of the latest performances confirm reactivity of the theatre, its power to concertize and subjectivize, as well as to model the audience's attitudes.

KEYwORDS: autobiography; performativity; Croatian theatre; interaction; documentary

\section{Wprowadzenie}

Eksploatowaniu narracji dokumentalnych i wykraczaniu poza sferę literatury fikcjonalnej pod koniec XX i na początku XXI wieku w dużej

${ }^{*}$ Praca powstała w ramach projektu badawczego nr 2017/24/C/HS2/00436, finansowanego ze środków Narodowego Centrum Nauki. 
mierze patronowała jawność życia publicznego, odkrywanie prywatności i widowiskowość intymności (Kasperski, 2001, 24). Przenikanie autobiografizmu do rozmaitych form wypowiedzi artystycznej cieszy się niesłabnącym powodzeniem w regionie postjugosłowiańskim i stanowi także jeden $\mathrm{z}$ dominujących trendów wśród współczesnych chorwackich twórców. Manifestuje się to nie tylko na polu literatury, ponieważ wiele autobiograficznych tropów odnaleźć można również na scenach teatralnych. W obszarze tym mieszczą się utwory zawierające wątki zaczerpnięte z życia autorów, ale też takie, które polegają na przetworzeniu dokumentów archiwalnych, transkrypcji zdarzeń, zeznań i wywiadów, a także gatunków autobiograficznych - dziennika i pamiętnika (Ślawska, 2013, 133).

O ile zagadnienie obecności żywiołu autobiograficznego w literaturze chorwackiej zostało szeroko opracowane - osiągnięciami w tej dziedzinie pochwalić się mogą zarówno lokalni badacze ${ }^{1}$, jak i polscy slawiści ${ }^{2}-$ o tyle odczuwalny jest wyraźny deficyt na tym gruncie, gdy mowa o próbach charakterystyki autobiograficznego wymiaru realizacji scenicznych. Do tej pory nie powstało ani rodzime, ani zagraniczne studium o współczesnym dramacie i teatrze autobiograficznym w Chorwacji. Dostępne są jedynie omówienia krytyczne i interpretacje poszczególnych projektów (których, by nie powielać treści, nie włączyłam do analizowanego materiału egzemplifikacyjnego), np. autorstwa Olivera Frljicia - Mrzim istinu (2011, Nienawidzę prawdy) lub Magdaleny Lupi - Jalova (2012, Jałowa), uwydatniające oparcie spektakli na faktach i inkorporowanie segmentów o charakterze testymonialnym. Prace te często sprowadzają się do zaprezentowania wytropionych treści wyjętych z życiorysów autora lub autorki bazowego tekstu dramatycznego.

Autobiograficzne archiwum jako twórczość, która „pomaga rozpoznać i umiejscowić się w świecie” (Lubas-Bartoszyńska, 2006, 53), nie posiada tylko wymiaru tekstowego, ponieważ forma, narracja i fabuła pozostają w ścisłym związku z jakościami dodatkowymi: pamięcią i zapominaniem, intymnym doświadczeniem, interpretacją osobistego przeżycia, ekspresją

\footnotetext{
${ }^{1}$ Obszerne prace poświęciły temu zagadnieniu m.in. Andrea Zlatar, Helena Sablić Tomić, Bernarda Katušić.

${ }^{2}$ Autobiografizm w literaturze chorwackiej stał się tematem rozważań naukowych np. Sabiny Giergiel, Magdaleny Ślawskiej, Leszka Małczaka, Katarzyny Majdzik, Ewy Szperlik, Magdaleny Dyras, Anity Gostomskiej.
} 
oraz kreacją (Bachura-Wojtasik, 2015, 111). Zawiera ono też potencjał performatywny, bowiem podmiot wychodząc od kreowania i inscenizowania „Ja”, nakierowany jest na stawanie się, wyswobodzenie oraz otwarcie na wymianę komunikatów (Grzemska, 2018, 78).

Wybrane projekty teatralne domagają się zatem analizy z uwzględnieniem opisu strategii wykorzystania autobiografii ujmowanej nie (lub nie tylko) jako gatunek niezależny, ale raczej jako (mniej lub bardziej obecną) funkcję w strukturze dzieła. Mikroświaty, osobiste punkty odniesienia do przełomowych wydarzeń, kontrnarracje, narracje alternatywne lub o charakterze autobiografikcji (Magnone, 2016, 519) ukazane zostają w spektaklach jako wymiary pamięci, która jest zawsze performatywna i nierozdzielna z działaniem (Sosnowska, 2017, 88). Jej ożywienie pozwala przede wszystkim na przemieszczenie - w znaczeniu ukonkretnienia i upodmiotowienia - które czasem wiąże się z zachowaniem pewnego marginesu tolerancji w rozporządzaniu faktami, by nie ,„atakować” widzów efektem rzeczywistości, a czasem narusza porządek symboliczny i wytrąca z równowagi. W proponowanym przeze mnie ujęciu klasyfikacyjnym jako ilustracje takich zabiegów wykorzystam wybrane przedsięwzięcia teatralne zrealizowane przez chorwackich artystów w ciągu ostatniej dekady. Ze względu na obfitość i złożoność materiału w prezentacji porządkującej okroję jednak rozważania teoretyczne, skupiając się wyłącznie na najważniejszych spostrzeżeniach.

\section{Sceniczna odsłona autobiografii}

W przypadku twórczości inkrustowanej treściami wydobytymi z życia autora lub autorki można mówić o pewnej predylekcji do utrwalenia siebie w konkretnej przestrzeni kulturowej, co istotnie przyczynia się do eksploracji, kształtowania i konstytuowania tożsamości (Lubas-Bartoszyńska, 2006, 53) oraz zmian w kolektywnej wyobraźni. Informacje zawarte w subiektywnych narracjach z powodzeniem nakreślają ramy przemian społecznych, ewolucji obyczajów oraz reorganizacji samowiedzy (Pekaniec,

${ }^{3}$ Termin ,,autobiografikcja” jest adekwatny dla autobiograficznego i po części autofikcjonalnego charakteru utworów. 
2012, 36), nawet jeżeli nie taka była intencja twórcy. Utwory te wypływają również z rozkoszy opowiadania (Lust zum fabulieren) lub, coraz częściej, z potrzeby wyzwolenia czy manifestu, rozpościerając się między autobiografizmem a ekshibicjonizmem (Frankowiak, 2009, 367). Powstają one spontanicznie lub są wywoływane przez okoliczności kluczowe dla jednostki, czasem takie, które posiadają status wydarzeń przełomowych. Nierzadko w wybranych utworach będących próbami werbalizacji traumy zidentyfikować można także sygnały aktywności (auto)terapeutycznej.

W teatrze, który ożywia i ucieleśnia autobiograficzne archiwa, w sposób szczególny przeplatają się ze sobą codzienność, historia i (mikro)polityka. W ten sposób współtworzą one mapę pamięci kulturowej danego kraju, ale składają się też na dzisiejszą tożsamość oraz przyczyniają do projektowania i uruchomienia przyszłości. Wiele najnowszych chorwackich realizacji wpisuje się częściowo w kategorię teatru rzeczywistości, którego pojemność nomenklatury i rozpiętość typologiczna sugerują bogactwo inwencji twórczej oraz głębię podejścia do formowania na nowo tego, co naprawdę miało miejsce. Niezależnie od stylu, teatr rzeczywistości niekoniecznie dokumentuje zaistniałe zdarzenia z pełną historiograficzną dokładnością (Martin, 2019, 10). W przypadku realizacji scenicznych obowiązują zatem także pewne ustalenia literaturoznawcze. Między innymi należy zwrócić uwagę na fakt, że artystyczne dawanie świadectwa obwarowane wymaganiami etycznymi i ograniczone paktem autobiograficznym jest już dość archaiczne. Obcowanie z utworami autobiograficznymi może wyzwolić podczas odbioru pęd do detekcji każdego sygnału autentyczności, jednak, jak zaznaczyła Sabina Giergiel (2012, 275), znacznie bardziej inspirujące jest tropienie w tekście obecności autora jako śladu. Poza tym, odbiorcy potrzebują raczej, by autor(ka) rzucił(a) im wyzwanie, podejmując prowokującą intelektualną grę i zamiast dokonywać wnikliwej autoanalizy, zwrócił(a) się ku nim, wciągając ich w skrupulatnie reżyserowany spektakl (Dąbkowska, 2019). Nowoczesny stosunek do tej materii zakłada kreację nie tylko siebie, o sobie, o otaczającym świecie, ale przede wszystkim dla kogoś.

Takie artefakty przesiąknięte autobiografizmem z zaprojektowaną sytuacją odbioru pełnią szereg funkcji, które mogą współwystępować i nakładać się na siebie. Inga Iwasiów przepisała narzędziami krytyki feministycznej autobiograficzny trójkąt (świadectwo - wyznanie - wyzwanie) 
zaproponowany wcześniej przez Małgorzatę Czermińską (2014, 30). W nowym ujęciu jego ramionami są: tożsamość - performans - komunikacja (Iwasiów, 2014, 9). W związku ze specyfiką ożywianego na scenie archiwum autobiograficznego proponuję nieco inne rozłożenie akcentów i naświetlenie cech oraz postaw takich jak: (re)konstruowanie tożsamości - performatywność - komunikacja i interakcja.

W praktyce przejawiają się one w różnym nasyceniu. Kamila Lasocińska $(2014,34)$ zwraca uwagę na możliwość różnych interpretacji wydarzeń życiowych (plastyczność interpretacji) i przekraczanie schematów myślowych poprzez komponowanie opowieści o swoim życiu. Dochodzi w niej wówczas do formowania narracyjnej tożsamości (zmieniającej się w czasie) i własnego obrazu „Ja” oraz refleksyjnego projektowania wizji swej przyszłości i określania zadań do realizacji. Charakterystyczne dla tych form, znajdujących się na pograniczu konfesji, eseju, traktatu naukowego, studium przypadku, pamiętnika i diariusza, jest również poczucie własnej niekoherencji, a także przekonanie o performatywności ról, w jakie wciela się podmiot lub które zmuszony jest podjąć.

W teatrze zarchiwizowane fragmenty życiorysów i okruchy przeszłości poprzez ich odkrywanie, ponowne wykorzystanie i odgrywanie zostają przywrócone obiegowi kulturowemu, ale odsłaniają też nowe wymiary performatywne (Bal, 2017, 19). Rozpatrywanie praktyk autobiograficznych w kategorii performatywności, upowszechnione w XXI wieku, pozwala doświadczać realizacji artystycznych jako archiwów kultury, świadectw historii i dokumentów biografii indywidualnej. Ponadto, wykorzystanie potencjału performatywnego może służyć samodefinicji danej kultury, wytwarzaniu wewnętrznych dynamicznych reprezentacji dotyczących pamięci i tożsamości, a także kształtowaniu relacji na poziomie wewnątrz-, a nawet międzykulturowym oraz pobudzaniu zmian i rozwoju.

Podmiot performatywny zazwyczaj nie jest podmiotem samotnym, lecz współdziała (często nieświadomie) z innymi podmiotami, ,aktorami” przestrzeni społecznej. Za pomocą praktyk artystycznych umocowanych na autobiograficznym podłożu próbuje nie tyle przekazać sens własnej opowieści, ile dokonać transformacji i transgresji wzbogacających działania innych. Reminiscencje animują pamięć faktograficzną i zmysłową na potrzeby stworzenia czegoś więcej niż pojedynczy obiekt mający reprezentować konkretne wydarzenia i momenty z życia. Głównym imperatywem 
staje się utrwalenie własnej podmiotowości wpisanej w szerszy kontekst i oddziaływanie na resztę poprzez powtarzalne akty artystyczne. Reinterpretowanie przeszłości i symulacja przyszłości możliwej - pożądanej lub niechcianej (Trzebiński, 2002, 80), może przekładać się na realne zmiany postaw i mentalności odbiorców, a w rezultacie zaważyć na pewnych daleko idących metamorfozach społecznych.

Działania na scenie ukonkretniają poruszane problemy, ale też ,nadpisują" treści podstawowe autobiografii, które bywają odczytywane w nowych rejestrach. W oparciu o przegląd realizacji teatralnych, w których sposób postrzegania i opisywania świata polega na przepuszczaniu go przez filtr odczuć i doświadczeń autora (Wnuk, 2011, 15), a często też aktorów i aktorek przemawiających w imieniu własnym, a nie scenicznych postaci, można dokonać umownej klasyfikacji. Wyróżnione linie odzwierciedlają koncentrację na tekście dramatycznym lub adaptację prozy, inspirację tekstami kultury kompilowanymi z wyznaniami i impresjami wykonawców oraz proces pozyskiwania, selekcji i opracowania materiału dokumentalnego.

\section{Tekst dramatyczny i adaptacja prozy}

Autobiografizm występujący w tekstach dramatycznych chorwackich twórców jest często ukryty, wpisany w fabułę i realia krajobrazowe, a przez to rozpoznawalny przede wszystkim w środowisku lokalnym. Wiele z tych propozycji wywołuje polemiki, na szczęście rzadko zdarza się, że autor i jego medialna atrakcyjność zbudowana niejednokrotnie na skandalach, a przynajmniej kontrowersjach, są istotniejsze niż wartość i odkrywczość utworu oraz unikalny temat czy styl. Przedstawiciele najmłodszej generacji dramatopisarzy: Dino Pešut lub Espi Tomičić, są wskazywani jako autorzy dokonujący redeskrypcji życia poprzez fikcję, jednak szczególną uwagę wzbudziła trylogia dramatyczna aktywnego od ponad trzydziestu lat Mate Matišicia Ljudi od voska (2016, Ludzie z wosku). Jej pojawienie się w obiegu czytelniczo-teatralnym sprowokowało do stawiania szeregu pytań dotyczących (ko)relacji prawdy i fikcji, życia i literatury, sfery prywatnej i publicznej, tajemnic rodzinnych i tabu społecznego. Ta dramatyczna suita zaprawiona groteską i parodią powstała na zamówienie dla 
Chorwackiego Teatru Narodowego w Zagrzebiu i zgodnie z zapowiedziami zawierać miała impresje z poszukiwań siebie uwzględniające opis rzeczywistych doświadczeń z pewnego etapu życia autora. Utwór składa się z trzech niezależnych i odrębnych stylistycznie części, których głównym łącznikiem jest Viktor, dramatopisarz i scenarzysta, a także były gwiazdor jugosłowiańskiego pop-rocka. Obok niego pojawiają się postaci ukształtowane tak, aby przypominały bliskich Matišicia. Bohater konfrontuje się ze swoją minioną młodością, wraca do rodzinnej wioski w Dalmacji, wraz z żoną zgadza się też zaopiekować dziewczynką, której matka umiera na raka, co ujawnia tłumione konflikty i mroczne tajemnice.

Tryptyk został opublikowany i klasycznie wystawiony (w wiernej reżyserii Janusza Kicy) bez zastrzeżenia, że jest fikcyjny. Matišić żonglując faktami ze swojego życia, krytykuje zaprogramowaną przez media silną potrzebę łowienia sensacji. Dramatopisarz ukazuje pole symulacji i demaskuje tym samym pewne mechanizmy modelowania sytuacji, zachowań i reakcji otoczenia. Wykorzystanie strategii autoreferencyjnych zdefiniować można jako rodzaj gry, a wprowadzona postać Mate skłania w swej otwartej spowiedzi do konkluzji, że w opowieści o sobie samym, która wprawdzie eksponuje to, co jest zazwyczaj przemilczane, dochodzi przecież do selekcji wycinków (auto)biograficznych i do (auto)cenzury. Zakwestionowana zostaje tu istota rzeczywistości i zapośredniczającego ją medium.

W najnowszej historii Chorwacji nie brakuje wydarzeń, które stały się nośnymi tematami literackimi. Wyróżniają się one swoją rozpoznawalnością i intensywnością polityk pamięci. Należy jednak uwzględnić zależność, że również małe „Zwykłe opowieści”, często sprzężone z punktami zwrotnymi w dziejach państwa, stanowią ramy dyskursywne, wewnątrz których funkcjonują pamiętające podmioty i zbiorowości. Wokół tych centrów ogniskują się działania artystów, które potwierdzają ważność indywidualnych, wręcz intymnych historii jako elementów poszerzających zakres rozumienia pewnych mechanizmów i interferencji.

W latach dziewięćdziesiątych XX wieku dostrzegalna była okresowa ekspansja literatury opartej na motywach autobiograficznych, na tle której wyróżnić można utwory określane syntagmą „literatura wojenna” (Małczak, 2003, 26). Podobnie do innych kręgów kulturowych, również w przypadku chorwackiego teatru jednym z jego charakterystycznych 
wyznaczników jest adaptacja prozy, także tej zorientowanej intymistycznie. Wybrane przyswajane przez realizatorów scenicznych koncepty pokrywają się miejscami z formułami zwrotu „dokumentalnego”, ,sentymentalnego”, „realistycznego”, „ku nowej szczerości”, ale twórcy spektakli zdecydowali się przede wszystkim na praktyki „ożywiania” wypierane przez logocentryczny dyskurs archiwum (i traktują je jak pełnoprawne media pamięci) oraz przekazywania wiedzy (Świątkowska). Dwa przedstawione poniżej spektakle są przykładami zastosowania technik prefiguracyjnych i renarracyjnych, które sprawiają, że inscenizacja nie jest jedynie prostym przeniesieniem tekstu na scenę, gdyż złożone procesy rewitalizacji i rekontekstualizacji zmieniają zasięg i oddziaływanie finalnego produktu artystycznego.

Premiera spektaklu Leica format w Chorwackim Teatrze Narodowym w Rijece (reż. Franka Perković, 2019) była oczekiwana z wielkim podekscytowaniem, ale też z uzasadnionymi obawami. Daša Drndić ${ }^{4}$, autorka tekstu bazowego, która w chorwackim świecie kultury miała szczególną pozycję, zaprezentowała dość krytyczną przesiedleńczą i „outsiderską” perspektywę. W powieści Leica format: fuge (2003, Leica format: fugi) Drndić uruchamia akcję rozpostartą między faktem a fikcją, łącząc współczesność z historią. Pisarka, która wiele lat swojego życia spędziła w Belgradzie, przybywa do Rijeki i narusza tryb czystego języka i jednorodności etnicznej. Na kartach książki stworzyła zwierciadło, w którym mieszkańcy miasta mogą się przeglądnąć, ale z pewnością nie upiększa tego wizerunku, a wręcz przeciwnie, konfrontuje ich z nieprzyjemną prawdą oraz podkreśla pewne problematyczne dla niej przejawy mentalności i środowiskowe anomalie. Opisując Rijekę przez pryzmat dualizmu ,wewnętrzny kontra zewnętrzny", autorka nieustannie bada powiązania między człowiekiem i miastem, tkając swego rodzaju geoautobiografię.

Podstawą powieści jest część narracyjna napisana w pierwszej osobie liczby pojedynczej, która początkowo jest identyfikowana jako autobiograficzna. W utworze uwidacznia się jednak pewien zamierzony zamęt tożsamościowy, ponieważ dwie kobiety: Antonia Host (alias Lydia Paut)

\footnotetext{
${ }^{4}$ Drndić była określana kontynuatorką świadomego pisarstwa kobiecego i twórczości zdeterytorializowanej (podobnie jak D. Ugrešić, S. Drakulić, P. Matvejević, S. Šnajder), ale jej nazwisko było łączone z nazwiskami autorów napływowych, którzy zostali włączeni do kanonu chorwackiej literatury (M. Jergović, J. Mlakić, M. Kovač, B. Ćosić).
} 
i Lea Moser (alias Tessa Koller) współtworzące z podmiotem wielogłos stają się jego metonimicznymi, wędrującymi przedłużeniami (Ryznar, 2014, 38). Kluczowa dla utworu fuga ${ }^{5}$ zostaje zwielokrotniona oraz rozpisana na nieskończoną mnogość głosów, powtórzeń i wariacji, dlatego w podtytule autorka zamieściła ten rzeczownik w liczbie mnogiej. Oznacza on multum narracji ułożonych jedna na drugiej w czasie i przestrzeni niczym polifoniczny raster. Co ciekawe, Drndić nie próbuje wprowadzić takiego ogromu głosów w harmonię symfoniczną, lecz zachęca je do interakcji (Ryznar, 2014, 37).

Dramaturg Goran Ferčec wyizolował z powieści ponad siedemdziesiąt postaci, które działają jako indywidualne lub zbiorowe głosy Rijeki, opowiadające o przeszłości i teraźniejszości miasta. Zrezygnowano z klasycznej psychologizacji bohaterów, natomiast wyodrębniono oraz rozbudowano kilka newralgicznych tematów, takich jak emigracja i uchodźstwo, utrata pamięci i kryzys tożsamości lub nawroty faszyzmu. W spektaklu główna bohaterka, „Ona”, która bierze na siebie rolę archiwistki, kompilatorki i dyrygentki, próbuje skłonić „,port różnorodności” do przemyśleń i przewartościowań oraz zainicjowania zmian na lepsze (miało to szczególny wydźwięk w obliczu zbliżającej się wówczas Europejskiej Stolicy Kultury Rijeka 2020).

Innym przykładem reorganizacji tekstu wyjściowego i ekspandowania jego funkcji jest projekt teatralny Hotel Zagorje (Miejski Teatr Dramatyczny Gavella, reż. Anica Tomić, dram. Jelena Kovačić, 2020). Nacechowana autobiograficznie powieść Ivany Bodrožić to wstrząsająca spowiedź o wygnaniu napisana z perspektywy dziewczyny, która musiała opuścić rodzinny Vukovar w 1991 roku. Utwór, w którym rozbrzmiewa głos anonimowego „słabego" świadka historii, wpisuje się w dyskurs slawońskiej literatury wojennej (Szperlik, 2013, 229). Główna bohaterka (postać utożsamiana z autorką), która dorasta w czasie wojny, jest wraz z mamą i bratem zmuszona do tułaczki po miejscach tymczasowego pobytu. Szukając wieści o ojcu - który zaginął w cieszącej się złą sławą miejscowości Ovčara,

${ }^{5}$ Fugę definiuje się jako ,uszkodzenie pamięci lub przedłużoną amnezję”, ,ucieczkę, zwłaszcza z ojczyzny, prześladowania, ale także przepędzenie”, „polifoniczną kompozycję muzyczną, której poszczególne partie powtarzają się zgodnie z pewnymi zasadami” oraz jako „celowo pozostawioną spoinę między kamieniami lub kafelkami [przeł. - G. A.]” (D. Drndić, Leica format: fuge, Zagreb 2003, s. 5-6, za: Ryznar, 2014, 36. 
gdzie torturowano i likwidowano przedstawicieli nieserbskich narodowości - osiedlają się na dłuższy okres w ośrodku pomocy, tytułowym „hotelu" w Chorwackim Zagórzu, czyli w budynku dawnej szkoły politycznej im. Josipa Broza Tity. Na każdym etapie rodzina doświadcza rozmaitych przejawów rozziewu, a nawet tarć między autochtonami a „obcymi”.

Jak zaznacza reżyserka Anica Tomić (2020), ,W spektaklu próba odnalezienia ojca przeradza się w poszukiwanie lepszej przyszłości i kraju, który nie byłby skorumpowany, bezwzględny i pozbawiony empatii, kraju, który roztoczyłby opiekę nad marginalizowanymi innymi, bo negatywny stosunek do nich po dziś dzień się nie zmienił [przeł. - G. A.]”. Współpracujące od wielu lat w duecie autorskim Tomić i Kovačić zdecydowały się na aktualizację przekazu oraz istotne modyfikacje dokonywane ze względu na wymogi sceniczne (kondensację, songi). Nie ograniczyły teatralnej eksploracji do utrudnionej przemiany dziecka w młodą kobietę, ale przedstawiły dorastanie całej generacji, jak również społeczeństwa. Spektakl został zadedykowany kobietom, co stanowi wyraźny znak dowartościowania ich punktu widzenia i roli, a także znajduje odbicie w doborze obsady - złożonej wyłącznie z aktorek. Reżyserka i dramaturżka (rówieśniczki pisarki) chcąc zbadać przystawalność utworu do obecnej sytuacji w kraju, poczyniły gruntowne przygotowania: przeczytały kompletny dorobek artystyczny Bodrožić (również opowiadania i wiersze), ale też wywiady z nią i artykuły prasowe. Ostatecznie realizatorki weszły w artystyczną dyskusję, łącząc część wspomnień zapisanych $\mathrm{w}$ powieści $\mathrm{z}$ własnymi doświadczeniami oraz przemyśleniami o tym, czym jest wojna i jak konflikt ukształtował całe pokolenie, a także jak rok 1991 odnosi się do współczesności.

\section{Aktywizacja aktorów - integracja wyznań}

Nieobce w chorwackim teatrze są przedsięwzięcia polegające na (de)montażu literatury i modułów pozaliterackich w taki sposób, aby uruchomić dialektyczny proces pomiędzy źródłem a nowymi dyskursami i aby myśl wystawiona na pokaz przeszła w działanie. Uwypuklony w ten sposób zostaje jednocześnie performatywny aspekt sieci intertekstów oraz otwarcie na rozmaite konteksty: historyczne, społeczne, polityczne, komunikacyjne i medialne (Sordyl, 2011, 44). Zasada ta urzeczywistniła 
się w spektaklu z elementami auto-teatru Kako smo preživjele (2014, Jak przeżyłyśmy), w którym faktografia zazębia się z autobiografią. Jego podwaliną jest przeznaczony dla zachodnich czytelników zbiór esejów Slavenki Drakulić Kako smo preživjeli komunizam i pritom se smijali (1992, Jak przeżyliśmy komunizm i jeszcze się przy tym śmialiśmy) nakreślający socjalistyczne realia, na napisanie którego autorka zdecydowała się za namową amerykańskiego wydawcy. Po ponad dekadzie (w 2005 roku) ta propozycja poświęcona kobietom, które według pisarki istotnie wpłynęły na zmiany zachodzące w krajach komunistycznych, została przetłumaczona na język chorwacki. W spektaklu to właśnie kobiety - sprawcze i operatywne, rewidują i rekonfigurują utopijną wizję Jugosławii. Osiem aktorek stara się odbudować poprzez osobiste wspomnienia pewną epokę, wyznaczając $\mathrm{w}$ tonie konfesyjnym przestrzeń, którą dzieliły i która wciąż do nich należy. Wraz z widzami ,przeżywają” na nowo komunizm, wojnę, tranzycję i transformację $e^{6}$, poświadczając o zjawiskach, które je zmieniły. Na uwagę zasługuje praca zespołu, który nie korzystał z gotowego skryptu dramaturgicznego, ale wytworzył go wspólnie od podstaw (uporządkowała go i skorelowała Željka Udovičić Pleština). Reżyser, Dino Mustafić, skłonił zaproszone do współpracy aktorki do podzielenia się własnymi retrospektywnymi spostrzeżeniami, co potwierdziło rozdźwięk między oficjalną i osobistą wersją historii. Rekonstrukcja polegała w znacznym stopniu na udostępnieniu jednostkowych archiwów pamięciowych artystek (powierzono im zadanie napisania wypracowań, z których następnie czerpano podstawowe motywy i skojarzenia), a powstałe dzięki temu projekcje korespondowały z dokumentalnymi sprawozdaniami Drakulić. Reżyser wyszedł od idei, że pamięć jest fundamentalnym komponentem ludzkiej tożsamości, a także nie pominął faktu, że sposób i wybór tego, co powinniśmy i co musimy utrwalać, jest ważną kwestią w rozwoju społeczeństwa.

${ }^{6}$ Terminy „tranzycja” i ,transformacja” bywają używane synonimicznie, jednak budzi to wśród specjalistów pewne wątpliwości. „Transformacja” oznacza systemowe przekształcenie, przeobrażenie czy przemieszczenie, „tranzycja” natomiast jest rozumiana jako okres przejściowy, dzielący dwa wyodrębnione momenty: początek rozmontowywania określonego reżimu politycznego oraz osiągniecie konsolidacji nowego. Piszą o tym A. Stelmach i S. Zyborowicz w opracowaniu Politologia a tranzycja systemowa w Polsce $(1998,154)$ oraz W. Morawski w książce Zmiana instytucjonalna. Społeczeństwo, gospodarka, polityka $(1998,35)$. 
Uniknął on jednak jugonostalgicznego zwrotu, próbując raczej uzmysłowić odbiorcom, jakie dziedzictwo pozostawił po sobie komunizm i okres wojny oraz co przyniosło wejście Chorwacji do Unii Europejskiej.

Nieco inaczej prezentuje się kwestia wplatania w tkankę spektaklu wyznań aktorów „od siebie i o sobie” w przypadku sztuki Eichmann u Jeruzalemu (2019, Eichmann w Jerozolimie) w reżyserii Jerneja Lorenciego (dram. Matic Starina). Tytuł projektu to znak nawiązania do sprawozdania Hanny Arendt dla „New Yorkera” i swego rodzaju szablon instruktażowy. Filozofka, która po obserwacji procesu sądowego Eichmanna stworzyła kontrowersyjną koncepcję banalności zła, dostrzegła także wysoki poziom medialności tego wydarzenia i wręcz obsesyjnie korzystała ze słownika przydatnego przy opisie przedstawień. Nie tylko to zajście, ale każdy akt składania świadectwa jest niewątpliwie naznaczony teatralnością, która wynika już z samej niezbędnej dla zaistnienia świadectwa konstelacji składającej się z osoby świadczącej i odbiorcy (słuchacza/widza) (Marszałek, 2017, 141).

Tekst Arendt był punktem wyjścia dla artystów z Zagrzebskiego Teatru Młodych do badań faktów historycznych, tekstów socjologicznych i filozoficznych, osobistych spostrzeżeń, a także znanych pierwiastków kultury popularnej w celu racjonalizacji i kontekstualizacji zła oraz jego konsekwencji. Konstrukcja opiera się w dużej mierze na zapożyczeniach z różnych tekstów kultury: filmu dokumentalnego Claude’a Lanzmanna Shoah, zbioru wykładów Karla Jaspersa opublikowanego jako Problem winy, powieści Skóra Curzio Malapartego, książki Borisa Pahora Necropolis i filmu Stanleya Kramera Wyrok w Norymberdze. Przyjęta konwencja wywołuje szczególny efekt, ponieważ oczekiwania, które towarzyszą śledzeniu adaptowanej fikcji, zostają rozbite. Brak tu sytuacji dramatycznej czy fabuły, a sekwencja jednostek narracyjno-wyznaniowych wypierających dialogiczną dynamikę tworzy strefę rozciągającą się od opowieści o re-edukacji, poprzez elementy re-kreacji do pasaży re-prezentacji (Čale Feldman, 2019, 130).

Sztuka rozpoczyna się przybliżeniem w tonie familiarnym i z humorystycznymi wtrętami wymagających przygotowań oraz etapów procesu badawczego. Obnażeni (bez scenografii i specjalnych kostiumów) aktorzy zwracają się bezpośrednio ad spectatores jako pracownicy kultury oraz jako ludzie z krwi i kości. Zaznaczają, że musieli napisać etiudy, szkice 
i monologi, a także przeanalizowali performatywność wydarzeń historycznych i epizodów z własnego życia. Dostarczają potem szczegółowych informacji z biografii nazistowskiego zbrodniarza, a następnie odtwarzają fragmenty zeznań więźniów, ożywiają obrazy z żydowskich gett i obozów koncentracyjnych oraz opisują proces Eichmanna, jego wygląd i zachowanie. W kolejnej odsłonie spektakl przenosi się na lokalny i, ostatecznie, osobisty poziom, a z interpretacji obiektywnych danych i biurokratycznych sprawozdań przekuwany jest w ,żywe” opowieści. Odkrywa się wówczas splot między tym, co kolektywne i tym, co indywidualne. Ultranacjonalistyczny zbrodniarz Andrija Artuković, przedstawiony (podobnie jak Eichmann) jako oskarżony w trakcie rozprawy, jest figurą unaoczniającą chorwacki kontekst. Po tym interludium następuje ciąg wypowiedzi aktorów, które mają charakter konfesyjny: artyści przywołują wspomnienia i tragiczne fakty dotyczące ich rodzin, wzbudzając współczucie i poczucie zaangażowania. Bardziej koordynator, a nie reżyser, jak określił siebie sam Lorenci, zmobilizował zespół na scenie do skontrastowania odgrywanej mechanicznie szczerości i uwolnionych emocji, co umożliwiło zatarcie granicy między różnymi porządkami oraz odejście od teatralnego rytuału. Skłania to widzów do zmiany optyki w rozważaniach na temat odpowiedzialności za zbrodnie i przebaczenia win, z czym zmagają się współcześnie obywatele Chorwacji.

\section{Teatralne opracowanie danych}

Godnymi uwagi są z pewnością działania teatralne, które za pomocą odpowiednich metodologii opracowywania danych poddają recyklingowi rzeczywistość na poziomie osobistym, ale też społecznym, politycznym czy historycznym. Twórcy dążą do rezonansu prawdziwego świata i do scenicznego upodmiotowienia świadków, których nierzadko zapraszają do współpracy. Między reprezentacją realnego wymiaru i jego fabrykacją, ale też między jednostkową i społeczną pamięcią tworzy się potencjalna przestrzeń rozumienia, uświadamiania i komunikacji.

Marina Petković Liker - reżyserka zawiadująca zagrzebską grupą teatralną „Četveroruka” (Czteroręka) - zorganizowała szereg innowacyjnych wydarzeń teatralnych, które w określony sposób łączą artystów 
i publiczność. Razem z performerką Sonją Pregrad uruchomiła laboratorium, w którym zajmują się badaniem kobiecej perspektywy w praktyce artystycznej pod kątem doboru tematyki, ale też formy i komunikacji. Artystkom nieobce jest wykorzystywanie materiału dokumentalnego, tak się też stało w przypadku przedstawienia Razgovaranje (2019, Rozmawianie). Jego fundamentem są nagrania zwierzeń kobiet - Serbek i Chorwatek z gminy Darda w Baranji - o doświadczeniach wojny i tworzeniu nowego początku w rzeczywistości powojennej. Reżyserka chciała, żeby przedstawiony w spektaklu splot głosów i gestów stanowił wyrazistą, a jednocześnie nieobciążoną nadinterpretacją artystyczną reakcję na autentyczne wypowiedzi prawdziwych ludzi i żeby wywołał poruszenie wśród publiczności. Razgovaranje to czwarty epizod cyklu Udaljenosti (Oddalenia) analizującego wymiar powojennych traum. Po przedstawieniach Udaljenosti - posustajanje (Oddalenia - odstępstwa), Udaljenosti - točka 285 (Oddalenia - punkt 285), Ni prijatelj ni brat (Ani przyjaciel, ani brat), ostatni segment koncentruje się na wysłuchaniu (również milczenia) i konfrontacji. Pracę nad nim zapoczątkowały wyjazdy w 2017 roku i działania $\mathrm{w}$ terenie, polegające na nagrywaniu kamerą i dyktafonem rozmów z zamieszkującymi Dardę kobietami, które opowiadały o najzwyklejszych sprawach i najgorszych doświadczeniach łączących je po dziś dzień.

Projekt wyrósł z potrzeby, by mówić o krzywdach, przebaczeniu i szukać opcji dialogu oraz odbudowy relacji. Historie te przeistoczyły się w komunikat o niemożliwości przedstawienia uniwersalnej i wyważonej historii o wojnie oraz trudnościach w uzyskaniu spójności w budowaniu jednej narracji. Realizatorki spektaklu organizują opowiadanie, wprowadzają komentarze do wydarzeń, porządkują układ między poświadczeniem wiarygodności i historii, między pragnieniem powiedzenia prawdy i pamięcią. Przedkładają one uchwycone niuanse, drżenie głosu, pauzy, spojrzenia, mowę ciała oraz poruszenie nad prowokacyjne i spektakularne serwowanie klasycznej skonsolidowanej opowieści i jednej autorytarnej prawdy. Podejmowanie tematów takich jak: utrata bliskich, domu, zerwanie stosunków oraz niemożność komunikacji, przeradza się w konstruktywną krytykę, która prowadzi do oczyszczenia i zmian. Mozaikowy obraz społeczeństwa po wojnie, odległy od tych, które dominują w przekazach medialnych i literackich, jest niezwykle przejmujący, a osoby z widowni twierdzą, że dzięki intymnej wręcz atmosferze (zakładającej bliski kontakt 
z widzem i wspólne spożywanie przekąsek) spektakl ma oddziaływanie terapeutyczne.

Największym osiągnięciem twórców projektów, w których na pierwszy plan wysuwa się dokumentowanie naiwne (komunikowanie bez przekraczania ustalonych konwencji) z obronną racjonalizacją i thumaczeniem swoich zamierzeń, jest indywidualizacja tragedii określonych grup. Przerażające liczby zmieniają się w konkretne historie, twarze i imiona, co wzmacnia nie tylko świadomość istnienia i zakresu danego problemu, ale też interakcję. Zasada ta obowiązuje również w przypadku twórczości zagrzebskiego Stowarzyszenia Kulturalnego „Arterarij”, które wygenerowało intrygującą trylogię teatralną ocierającą się o teatr stosowany, teatr dokumentalny i eksperymentalny oraz terapię poprzez teatr. Bazuje ona na wyznaniach przedstawicieli marginalizowanych i stygmatyzowanych grup. Dyrektor artystyczny „Arterarij” i reżyser Romano Nikolić dąży konsekwentnie do włączania w produkcje artystyczne autentycznych głosów wykluczanych Innych. Pierwszy spektakl Pogledajme (2016, Spójrznamnie ${ }^{7}$ ) w wykonaniu członków społeczności romskiej okazał się prawdziwym przełomem. Fundamentem sztuki są opowiedziane sytuacje, których świadkami lub uczestnikami byli występujący na scenie Sindi i Siniša (funkcjonowanie w szkole, rozmowa w sprawie pracy, incydenty na ulicy), a osobisty ton zostaje przełamany refleksjami i komentarzami dotyczącymi wspólnych problemów Romów, takich jak rasizm, szowinizm i eksterminacja przez III Rzeszę.

Kolejny inkluzyjny projekt sceniczny Stowarzyszenia zatytułowany Čekanja (2018, Oczekiwania, autor: Romano Nikolić, dram. Mila Pavićević, reż. Ozren Prohić) ponownie poświęcono kwestii Inności, odpowiedzialności społecznej i wrażliwości, ale z perspektywy uchodźców. Jego osią stała się historia pochodzącego z Iraku małżeństwa, które znalazło azyl w Chorwacji. Wykonawcy opowiadają o dramatycznych i absurdalnych wydarzeniach, które poprzedzały przyjazd, od momentu ich poznania się i decyzji o związku (nieakceptowanym, ponieważ on jest szyitą, a ona sunnitką), przez rozpoczęcie wojny domowej w ojczyźnie, po rozstanie i podróż, a potem ponowne spotkanie. Bohaterowie zwracają się do

\footnotetext{
${ }^{7}$ Goście z „Arterarij” zaprezentowali spektakl podczas olsztyńskiego Międzynarodowego Festiwalu Teatralnego Demoludy-Nowa Europa w 2018 roku.
} 
publiczności po angielsku i arabsku (kobieta tłumaczy wypowiedzi męża, który posługuje się najczęściej „simple English”). Tytuł sztuki w równym stopniu odnosi się do zawieszenia mężczyzny w stanie wyczekiwania na granicach i w prowizorycznych obozach dla uchodźców, czekania na wieści o losie jego bliskich, ale można go również odczytać jako beckettowskie oczekiwanie na zmianę, która prawdopodobnie nigdy nie nastąpi. Intymną atmosferę wzmocniła okresowa prezentacja kameralnego spektaklu w pokojach pustego mieszkania w centrum Zagrzebia, gdzie wówczas rozgrywało się życie tej pary, a także użycie tylko elementarnych środków teatralnych oraz odejście od efektów scenicznych.

Tryptyk zamyka autorski projekt Posljedice (2018, Następstwa, reż. Romano Nikolić, dram. Jasna Jasna Žmak), w którym podjęto problem przemocy wobec kobiet. Tym razem wykonawcami nie są przedstawiciele uciskanej mniejszości i naturszczycy, ale profesjonalne aktorki, jednak jedna z nich - Sandra Petrž - nie odgrywa fikcyjnej postaci, lecz reprezentuje samą siebie - ofiarę przemocy domowej. Proces twórczy opierał się na opracowaniu materiałów o charakterze dokumentalnym i osobistych świadectw, również wyznań opublikowanych w zbiorze Istinite priče zlostavljanih (Prawdziwe opowieści wykorzystywanych), zredagowanych przez wspomnianą aktorkę, a także zwierzeń samej Petrž przestawionych w autobiografii Sandročka zlostavljana (Sandrunia Wykorzystywana) i w tomikach poezji nawiązujących do życia autorki Istina to sam ja (Prawda to ja) i Duša nedokučivih svjetova (Dusza przepastnych światów). Wymienione przedsięwzięcia z imperatywem zaangażowania współistnieją wprawdzie jako zamknięty cykl dokonań Stowarzyszenia „Arterarij”, jednak jego kontynuacją jest najnowszy, stricte konfesyjny spektakl Laboratorij: Tužne pjesme za sretne susrete (2020, Laboratorium: smutne wiersze na szczęśliwe spotkania, reż. Romano Nikolić, dram. Dorotea Šušak) stanowiący liryczno-performatywny obraz konfrontacji z różnymi postaciami straty.

\section{Podsumowanie}

Rejestrowanie faktów z życia ujawnia indywidualne interpretacje i przekłada się na działania o charakterze (auto)kreacyjnym (Lasocińska, 2014, 34), projekcyjnym, interakcyjnym, a nawet interwencyjnym. 
Przetwarzana w osobistych zapisach i wyznaniach rzeczywistość (w przypadku współczesnej twórczości w Chorwacji - rzeczywistość wojenna, ale też kształtująca się w okresie tranzycji i najnowszych przemian) nierzadko obfituje w doświadczenia związane z procesami tożsamościowymi, umykające linearnej narracji i niemieszczące się w stabilnych formach. Mogą one wybrzmieć pełniej, gdy zamknięte repozytorium przeistacza się w żywe, otwarte na przepływy archiwum. Ożywianie literackich i pozaliterackich formuł faktu oraz autobiografii stało się w teatrze chorwackim pewną tendencją. Należy jednak zaznaczyć, że twórcy wybranych spektakli nie trzymają się kurczowo wytycznych dokumentu, ale przeobrażają materiał podstawowy (nieustannie refigurowany przez wszystkie prawdziwe lub fikcyjne mikronarracje; Ricoeur, 2008, 353) i poddają go (de) montażowi. W swoich zaangażowanych projektach - od instytucjonalnych i mainstreamowych do kameralnych i offowych - zamiast pasywnego odbioru i suchego odtwarzania proponują oni aktywną konfrontację z upodmiotowioną oddolną (re)wizją rzeczywistości, co bezsprzecznie pobudza krążenie energii społecznej.

Performans jawi się zatem jako archiwum - przepisujące historię na ciało, zawieszające granicę między tym, co martwe a tym, co żywe (Sosnowska, 2017, 85) - oraz przekracza stabilność i hermetyczność dokumentu. Sceniczne opracowanie tworzywa autobiograficznego nie jest procesem ukierunkowanym tylko na kopiowanie oryginału. Ożywienie tego archiwum w performatywnym geście umożliwia bowiem interakcyjne badanie i dostęp do wydarzenia w bardziej bezpośredni i afektywny sposób niż standardowe analityczne podejście podczas lektury.

Przybliżone w pracy realizacje sceniczne nagłaśniają niedostatecznie komentowane lub wypierane problemy, skłaniają do pogłębionej refleksji i dyskusji. Potwierdzają one także „karierę i nośność autentyku” prowokującą do współuczestniczenia oraz założenie, że „fakty, dokumenty, przekazy historyczne mają siłę dramatyczną i artystyczną silniejszą od wielkiej kreacji" (Grochola, 1981). Ponadto, ekspresja autobiograficzna $\mathrm{w}$ przestrzeni komunikacyjnej teatru i w przekazie czynnego działania ,z ciała do ciała" ma emancypacyjny oraz prawdziwie polityczny wymiar (Sosnowska, 2017, 86). 


\section{Literatura}

Bachura-Wojtasik, J. (2015). Biografia i autobiografia w literaturze audialnej. „Acta Universitatis Lodziensis. Folia Litteraria Polonica" nr 2 (28), s. 107-120.

Bal, E. (2017). Lokalność i mobilność kulturowa teatru Śladami Arlekina i Pulcinelli. Kraków: Wydawnictwo Uniwersytetu Jagiellońskiego.

Čale Feldman, L. (2019). Onkraj pozornice. Na raskrižju medija. Zagreb: Disput.

Czermińska, M. (2014). Autobiograficzny trójkąt. Świadectwo, wyznanie i wyzwanie. Kraków: Universitas.

Dąbkowska, P. (2019). Beksiński, „Beksiński”, Bexiński? Między autobiografia, kreacją a tożsamościa (anty)bohatera. „Nowy Napis” nr 12. https://nowynapis.eu/tygodnik/nr-12/artykul/beksinski-beksinski-bexinski-miedzy-autobiografia-kreacjatozsamoscia. 30.06.2020.

Drndić, D. (2003). Leica format: fuge, Zagreb: Meandar.

Frankowiak, A. (2009). Między ekshibicjonizmem a autobiografizmem. Literatura najnowsza w obszarze intymności (ciota - Żydowica - odludek). „Napis” ser. XV, s. $365-374$.

Giergiel, S. (2012). Ocalić pamięcią. Praktyki pamięci i zapominania we współczesnej prozie postjugosłowiańskiej. Opole: Wydawnictwo Uniwersytetu Opolskiego.

Grochola, W. (1981). Poznań, Czerwiec 1981. „Tygodnik Solidarność” nr 14.

Grzemska, A. (2018). Matki i córki w polu autobiograficznym. „Teksty Drugie” nr 6, s. 77-91. https://doi.org/10.18318/td.2018.6.5.

Iwasiów, I. (2014). Tożsamość, performatywność, komunikacja - genderowe aspekty autobiografizmu. „Autobiografia. Literatura. Kultura. Media” nr 1 (2), s. 7-11.

Kasperski, E. (2001). Autobiografia. Sytuacja i wyznaczniki formy. W: Autobiografizm. Przemiany, formy, znaczenia. Red. H. Gosk, A. Zieniewicz. Warszawa: Dom Wydawniczy i Handlowy Elipsa, s. 10-26.

Lasocińska, K. (2014). Autobiografia jako autokreacja. Twórcze aspekty procesu myślenia autobiograficznego w edukacji dorostych. W: Biografie edukacyjne. Wybrane konteksty. Red. E. Dubas, J. Stelmaszczyk. Łódź: Wydawnictwo Uniwersytetu Łódzkiego, s. 33-46. https://doi.org/10.18778/7969-353-5.03.

Lubas-Bartoszyńska, R. (2006). Nowsze problemy teoretyczne pisania o sobie. Przyklad wypowiedzi autobiograficznych pisarzy polskich ostatnich dziesięcioleci. „Przestrzenie Teorii” nr 6, s. 51-67. https://doi.org/10.14746/pt.2006.6.5.

Magnone, L. (2016). Emisariusze Freuda. Transfer kulturowy psychoanalizy do polskich sfer inteligenckich przed druga wojna światowa, t. 1. Kraków: Universitas.

Małczak, L. (2003). Panorama autobiograficznej prozy chorwackiej lat 90-tych XX wieku, czyli o chorwackiej literaturze wojennej (hrvatsko ratno pismo). „Pamiętnik Słowiański" t. 53, s. 25-38.

Marszałek, M. (2017). Świadectwo jako performans. „Dialog” nr 7-8, s. 141-151.

Martin, C., (2019). Świadectwa artystyczne: teatr rzeczywistości. Przeł. M. Paprota, B. Wójcik. „Dialog” nr 1, s. 5-19. 
Morawski, W. (1998). Społeczeństwo, gospodarka, polityka. Warszawa: Wydawnictwo Naukowe PWN.

Pekaniec, A. (2012). Autobiografie w literaturoznawstwie i socjologii. Rozbieżności i styczne (Wstęne rozpoznanie teoretyczne). „Państwo i Społeczeństwo” nr 1, s. 27-52.

Ricoeur, P. (2008). Czas opowiadany. Czas i opowieść, t. 3. Przeł. U. Zbrzeźniak, Kraków: Wydawnictwo Uniwersytetu Jagiellońskiego.

Ryznar, A. (2014). Interdiskurzivne fuge u romanu Leica format Daše Drndić. „Fluminensia” nr 1, s. 35-46.

Sordyl, A. (2011). Adaptacja jako twórcza praktyka w polskim teatrze współczesnym. Krystian Lupa - Krzysztof Warlikowski - teatr krytyczny. „Postscriptum Polonistyczne" nr 2 (8), s. 43-60.

Sosnowska, D. (2017). Ciało jako archiwum - współczesne teorie teatru i performansu. W: Świadectwa pamięci. W kręgu źródet i dyskursów (od XIX wieku do dzisiaj). Red. E. Dąbrowicz, B. Larenta, M. Domurad. Białystok: Alter Studio, s. 79-89.

Stelmach, A., Zyborowicz, S. (1998). Politologia a tranzycja systemowa w Polsce. W: Politologia w Polsce: stan badań i perspektywy rozwojowe. Materiaty konferencji naukowej. Red. T. Łoś-Nowak. Wrocław: Wydawnictwo Adam Marszałek, s. $149-158$.

Szperlik, E. (2013). Opisać wojnę? Doświadczenie traumy w chorwackim dyskursie autobiograficznym i literaturze świadectwa o wojnie w bytej Jugostawii 1991-1995. „Miscellanea Posttotalitariana Wratislaviensia” nr 1, s. 225-245.

Ślawska, M. (2013). Proza autobiograficzna pokolenia jugonostalgików. Wrocław: Atut.

Świątkowska, W. Re-enactment. W: Encyklopedia Teatru Polskiego. Elektroniczna baza wiedzy. http://encyklopediateatru.pl/hasla/352/re-enactment\#. 30.06.2020.

Tomić, A. (2020). Naš „Hotel Zagorje” priča je o društvu koje nikada nije sazrelo. „Tportal.hr”. https://www.tportal.hr/kultura/clanak/anica-tomic-o-predstavi-hotelzagorje-u-gavelli-to-je-prica-o-ptsp-u-ove-zemlje-20200130. 30.06.2020.

Trzebiński, J. (2002). Narracja jako sposób rozumienia świata. Gdańsk: GWP.

Wnuk, A. (2011). Powieść poetycka wobec autobiografii. „Świat Tekstów. Rocznik Słupski” nr 9, s. 15-34. 